\title{
FRASA PREPOSISIONAL BERMAKNA TEMPAT DALAM KALIMAT BAHASA BUGIS: SUATU KAJIAN STRUKTUR DAN SEMATIK
}

\author{
Haedariah \\ Universitas Lakidende \\ e-mail: Haedariahedha@gmail.com
}

\begin{abstract}
The research entitled "Prepositional Phrases Meaningful Places in Bugis Sentences" describe prepositions in Bugis in terms of form, meaning and category. The method used in this research is descriptive distribution. The main data of this research comes from written language, while the oral and artificial data are used as supporting data. The research aims to (1) describe the prepositions of the meaning of places in Buginese, (2) describe the linguistic elements associated with Bugis language prepositions, (3) describe the functions occupied by prepositional phrases meaning place in Bugis language, and (4) describe the meaning the place contained in the prepositions in the Buginese language. The results of this study.
\end{abstract}

Keywords: Prasa, Preposition, Linguistic Elements, Syntax Function 


\section{LATAR BELAKANG}

Manusia hidup dengan latar belakang budaya yang memiliki tipologi wilayah geografi yang berbeda-beda. Kebudayaan yang dimiliki manusia salah satunya adalah bahasa. Keanekaragaman budaya akan menghasilkan bahasa yang bervariasi, seperti bahasa daerah. Bahasa daerah merupakan cermin budaya yang dipegang teguh oleh para penuturnya untuk berkomunikasi.Salah satu bahasa daerah yang saat ini masih banyak dipegang teguh oleh para penuturnya adalah bahasa Bugis.Bahasa Bugis merupakan salah satu bahasa ibu atau bahasa pertama yang sampai sekarang masih sangat kental dan kuat di daerah Sulawesi Selatan.

Sebagaimana diketahui bahwa daerah Provinsi Sulawesi Selatan ini terdiri dari beberapa kabupaten dan kota yang pada umumnya berasal dari kerajaan-kerajaan di masa lampau. Dari sekian banyak daerah kabupaten dan kota yang tergolong sebagai daerah yang mayoritas penduduknya menggunakan bahasa Bugis sebagai bahasa sehari-hari adalah Bone, Wajo, Soppeng, Sidenreng- Rappang (Sidrap), Pinrang, Parepare, Barru, Pangkajene- Kepulauan, (Pangkep), Maros, Bantaeng, Bulukumba, dan Sinjai (Rafiuddin, 1980: 12).

Walaupun semua daerah tersebut di atas mengakui bahasa daerahnya adalah bahasa Bugis,tidaklah dapat dikatakan bahwa bahasanya itu benar-benar sama karena hampir semua daerah tersebut mempunyai perbedaan, salah satunya dari aspek dialek (Rafiuddin, 1980: 13).

Bahasa Bugis telah menjadi alat komunikasi dalam kehidupan masyarakat penuturnya.Masyarakat penutur bahasa Bugis menggunakan bahasanya untuk berbagai tujuan. Dalam konteks penggunaan bahasa Bugis di setiap daerah, tidak tertutup kemungkinan terdapat pemunculan bentuk kata yang sama, tetapi me-miliki makna yang berbeda. Perbedaan makna sering menimbulkan perbedaan persepsi dan interpretasi antara pembicara dan pendengar, antara penulis dan pembaca yang berbeda dialek atau daerah asalnya.Dalam hal ini, kesalahan per-sepsi dan interpretasi terhadap makna kata karena kata tersebut kemungkinan me-miliki makna lebih dari satu.

Bahasa Bugis merupakan bagian dari suatu kebudayaan yang berkembang di tengah-tengah masyarakat dan diwariskan turun-temurun secara lisan sebagai milik bersama.Bahasa Bugis merupakan salah satu kebudayaan yang perlu diteliti dengan sungguh-sungguh sehingga bahasa Bugis dapat dipahami makna dan bunyi bahasanya. Bahasa Bugis yang dipahami oleh orang Bugis Sulawesi Selatan adalah Bugis yang memiliki tulisan sama, bacaan sama, tetapi berbeda makna dan yang membedakan bahasa Bugis adalah intonasi kata (Fachruddin, 1981:1).

\section{METODE PENELITIAN}

Metode yang digunakan dalam penelitian ini adalah kualitatif dengan data bahasa Bugis Sulawesi Selatan.Data kualitatif adalah data yang dikumpulkan dengan tidak dihitung jumlah atau kekerapan munculnya, tetapi peristiwa dan fenomena yang dikaji dan ditelaah secara mendalam.Penelitian ini mengkaji dan menganalisis data secara objektif berdasarkan fakta kebahasaan yang ada feno-mena yang memang secara empiris hidup pada penuturnya.Metode ini memuat tahapan strategis yang terbagi atas tiga bagian yaitu metode pengumpulan data, analisis data, dan penyajian analisis data (Sudaryanto, 1993:57).

Penelitian yang dilakukan pada preposisi bahasa Bugis bertujuan untuk menata tata cara berbahasa dalam masyarakat Bugis. Sesuai dengan objek sasaran penelitian, 
yaitu preposisi dalam bahasa Bugis dan sesuai pula dengan tujuan penelitian, metode pengumpulan data yang dipergunakan ialah metode simak.Pengumpulan data dengan simak-catat penggu-naan preposisi bahasa Bugis, baik dalam media online maupun pada cerpen atau puisi.

Karena preposisi itu cenderung banyak terdapat di dalam bahasa tertulis, penyimakan terhadap preposisi bahasa Bugis di dalam puisi atau elong Bugis lebih banyak dilakukan.Penyimakan itu dilakukan dengan teknik catat.Hasil pencatatan itu diseleksi untuk dituliskan di dalam kartu data. Seandainya belum ditemukan tipe pemakaian preposisi yang diharapkan, penelitian masih harus menambah data lagi dengan metode yang sama atau dengan menggunakan metode cakap, yaitu pengumpulan data dengan melakukan kontak antara peneliti dan informan (Sobarna, 2012).

\section{HASIL PENELITIAN}

\section{Jenis Preposisi dalam Bahasa Bugis yang Bermakna Tempat}

Ada beberapa kreteria yang digunakan oleh penulis tata bahasa Indonesia dalam memberikan definisi preposisi kriteria-kriteria tersebut berkisar pada (1) bentuk, (2) distribusi, dan (3) fungsi preposisi.

Manifestasi kriteria 'bentuk' dalam definisi preposisi tercermin dalam bentuk ungkapan-ungkapan seperti; "preposisi adalah partikel", “...tidak mengalami perubahan bentuk", dan "...tidak mengalami infleksi". Manifestasi kriteria fungsi terlihat pada ungkapan-ungkapan seperti: ..."menyatakan pertalian kata benda tertentu dengan kata lain dalam kalimat”, “...menyatakan pertalian makna kata-kata atau bagian-bagian kalimat", atau "penanda dalam konstruksi frasa eksosentrik".

Keanekaragaman itu melahirkan bermacam-mcam definisi preposisi. Selain itu, istilah yang digunakan pun bermacam-macam. Di samping istilah preposisi di gunakan pula istilah kata depan, kata perangkai, kata penyelit, dan kata sambung. Dalam penelitian ini untuk seterusnya digunakan istilah Paddairiolo 'preposisi'.

Lahirnya istilah yang bermacam-macam itu antara lain disebabkan oleh pandangan yang tidak sama dari ahli-ahli tata bahasa Indonesia dalam men-definisikan preposisi. Ada yang berpandangan tradisional dan ada pula yang berpendapat struktural.

Mengklasifikasi preposisi dalam penelitian ini bertujuan menjelaskan dan menganalisis tentang kedudukan dan fungsi preposisi dalam bahasa Bugis. Seperti yang telah dikemukakan pada pendahuluan di muka. Fungsi preposisi di dalam bahasa Bugis preposisi dikenal dengan sebutan paddairiolo 'kata depan' dalam bahasa Bugis. Yaitu, kata depan atau bisa juga disebut kata yang menghubungkan kata yang satu dengan kata yang lain, juga tidak membedakan antara paddairiolo 'preposisi' dan konjungsi, yang juga disebut kata sambung atau kata penghubung.

Preposis gabungan ialah terdiri atas (1) dua preposisi yang berdampingan dan (2) dua preposisi yang berkolerasi.

(1) a. Kami berjalan sampai ke bukit.

b. Selain dari kakanya ia juga cantik.

c. Tanaman itu mati oleh sebab kekeringan.

(2) a. Saya tidak bertemu dengan beliau lagi sejak rapat itu hingga kini

b. Kami pindah dari Makassar ke Jakarta tahun lalu.

c. Antara dia dan adiknya ada perbedaan yang mencolok. 
Pada contoh (1) terdiri atas dua preposisi yang letaknya berurutan. Dan jenis preposisi gabungan terdiri atas dua unsur yang dipakai berpasangan, tetapi terpisah oleh kata atau frasa lain.

Namun berbeda paddairiolo 'preposisi' di dalam bahasa Bugis, tentang preposisi yang berdiri sendiri dan preposisi gabungan, yang dimaksud dengan preposisi tunggal atau preposisi berdiri sendiri dalam penelitian ini adalah pre-posisi yang terdiri atas satu preposisi dalam satu kalimat, atau kehadirannya berdiri sendiri tidak terikat oleh preposisi lain perhatikan contoh data berikut:

(3) a. La Andi / cemme / ri / kollang'e / ro.

b. Andi / sedang / mandi / di / kolam / itu.

c. 'Andi sedang mandi di kolam itu'.

(4) Tabbekkadua / ri / panre / manu'-e / ele / araweng

Selalu dua kali / di / beri makan / ayam itu / pagi dan sore

'Ayam itu di beri makan pagi dan sore'.

Kemudian yang dimaksud paddairiolo 'preposisi' gabungan, preposisi yang berkaitan dengan verba yang dinamis 'bergerak' penulis mendeskripsikan ialah preposisi ketika dilihat dari segi sintaksis dan semantiknya tidak mempunyai makna jika tidak diikuti oleh preposisi $r i$ 'di' perhatikan contoh berikut.

(5) Elo'/ ka/lokka/makbura/ri/rumah/saki.

mau / saya / pergi / berobat / di / rumah / sakit.

'Saya mau berobat ke rumah sakit'.

(6) Elo'/ $\mathrm{ka} /$ lokka / ri / salong'e / marrette'/gemme / ku

Mau / saya / pergi / di / salon / memotong / rambut / saya

'Saya mau pergi ke salon memotong rambut saya'.

Dalam kalimat frasa preposisi dapat menduduki fungsi predikat dan keterangan. Fungsi keterangan merupakan fungsi yang umum diduduki oleh frasa preposisi, begitupula dengan kalimat dalam bahasa Bugis.

Preposisi dalam bahasa Bugis hanya ada tiga jenis yang dikenal dengan sebutan $r i$ 'di', elo 'ke', dan pole 'dari'. Preposisi atau paddairiolo dalam bahasa Bugis dapat dikelompokkan menjadi dua kelompok, yakni (1) preposisi tunggal atau berdiri sendiri dan (2) preposisi gabungan.

\section{Preposisi Tunggal}

Paddairiolo 'preposisi'dalam bahasa Bugis dapat dinyatakan sebagai tanda pertalian antara dua wujud, yakni pelengkap preposisi dan bagian lain dalam kalimat, yang dimaksud dengan preposisi tunggal atau preposisi berdiri sendiri dalam penelitian ini adalah preposisi yang terdiri atas satu preposisi dalam satu preposisi selain itu, preposisi yang bertalian secara bentuk dan mempunyai distribusi yang sama diperlakukan sebagai satu preposisi, preposisi ri 'di' dapat dipakai di depan kata benda yang menyatakan makna tempat tertentu (selain dari nama wilayah dan negara) dan makna tempat yang berbentuk nama orang perhatikan contoh berikut:

Paddairiolo 'preposisi' $r i$ 'di' $+\mathrm{N}$ (tempat tertentu selain nama wilayah dan Negara dan nama orang) 
(7) Situjuan pada / leppanna / maccinaung / ri / awa na / seua'e / batoa / ri / sere / laleng / namukka / bosi / rajana ( Fachruddin, 1981: 31).

Oleh karena itu / singgah / bernaung / di / bawah / sebatang / besar/di / tepi / jalan / karena / hujan / besar.

'Oleh karena hari itu hujan lebat mereka singgah bernaung di bawah sebatang pohon besar di tepi jalan.

(8) Na iaro / jama-jamanna / lao'e / mabbukk / kaju / ri wirinna / tanete / sibawa / ri / wirimpalenna'e (Fachruddin, 1981: 39)

Dan itu / pekerjaannya / pergi / mencari / sayur / di / pinggir / padang / bersama / di pinggir / sungai.

'Mata pencaharian mereka hanya mencari sayur-sayuran $d i$ tepi padang atau di pinggir sungai.

Paddairiolo 'preposisi' $r i$ 'di' digunakan di depan kata benda yang menyatakan nama tempat baik kota, desa, maupun ruang/tempat lainnya pola pemakaianya $r i$ 'di' $+\mathrm{N}$ (kota, desa, dan tempat lainnya).

(9) Makkuniro / amulangenna / batu / maddupa-rupang / engka e / lettu / esso / awo / ri / liang / mampu (Fachruddin, 1981: 30).

Begitulah / pertama / batu / macam rupa / yang ada / sampai / hari di / lobang / mampu (Bone).

'Demikianlah asal mulanya batu beraneka ragam yang ada diGoa mampu (Bone) hingga saat ini.

Preposisi tidak hanya menjadi pembatas tetapi juga dapat menjadi penguasa. Dalam frasa preposisi, preposisi berlaku sebagai penguasa sedangkan unsur lain (dalam hal ini lazimnya nomina/pronomina) menjadi pembatas.

Dalam bahasa Bugis pembatas preposisi yang ditemukan hanya terdiri dari kategori nomina baik benyawa maupun tidak bernyawa dan pronomina. Dengan kata lain yang menjadi pembatas dalam prasa preposisi dalam bahasa Bugis adalah kategori nomina dan pronomina.

\section{Preposisi Gabungan Elo ' ke'}

Yang dimaksud preposisi gabungan penulis mendeskripsikan ialah preposisi elo'ke' ketika dilihat dari segi sintaksis dan semantiknya tidak mempunyai makna elo 'ke' dan tidak dapat berdiri sendir jika tidak diikuti oleh preposisi ri 'di'. Namun, terkadang preposisi gabungan elo 'ke' dapat berdiri sendiri ketika verba yang mendampinginya verba aktivitas, kemunculan suatu preposisi dalam suatu konsrtuksi dapa dipngaruhi oleh konsituen sebelumnya, dalam hal ini predikat yang menguasai kemunculan preposisi dapat berupa verba dapat pula adjektiva. berdasarakan semantiknya, verba dasar yang menguasai kemunculan preposisi dapat berupa verba aktifitas, pungtual, statis, dan statip. Perhatiakan contoh berikut:

(10) Iana / saba'na / pamarenta'e / makkukuae / makkuragai / bara'kuammengngi / pabbanuae / ri / kotae / Elo / lao / ri / kampong'e, (Daud,dkk., 1989: 61).

Itulah / sebabnya / pemerintah / sekarang / berbuat / semoga / orang / kampung / yang ada di kota / mau / pergi / ke / kampung 'itulah sebabnya pemerintah sekarang berbuat semoga orang kampung yang ada di kota mau kembali $\mathrm{Ke}$ kampung'. Allah / Taala'/ asenna / latok passompek (Fachruddin, 1981: 34 
Ada / puang / Nenek / saya / kembali / di / Rahmat / Allah / yang bernama / latok / Passompek.

'saya mempunyai nenek yang bernama latok Passompek, yang telah kembali ke Rahmat Allah;

(11) Purai ro / lisuni / paimeng / I nyamekkininnawa / ri bolana / natiwi'i / lunrak/jongana (fachruddin, 1981: 39)

Sesudah itu / pulang / kembali / si baik hati / ke rumahnya / membawa/ lemak / rusanya

'kemudian kembalilah si baik hati ke rumahnya membawa lemak rusanya'.

(12) Elo’i / La Mellong / lokka / ri / darek / na / mattaneng / relle.

La Mellong / mau / pergi / ri / kebun / nya / menanam / jagung

'La Mellong mau pergi ke kebunnya menanam jagung'.

Pada data (11), dan (12), verba dinamis yakni lokka 'pergi' lisu 'pulang' sebagai penguasa memicu hadirnya preposisi yang mempunyai ciri dinamis, yakni elo/ mau 'ke', pole/ datang 'dari'.

Kategori yang menjadi penguasa hadirnya sebuah preposisi dalam kalimat adalah jenis kategori vrba. Dengan kata lain, frasa preposisi sebagai pembatas hubungan ditentukan oleh kategori verba yang menjadi penguasanya. Dalam hal ini, preposisi dalam sebuah kalimat berlaku sebagai pembatas.

Di pihak lain (frasa preposisi), preposisi berlaku sebagai penguasa. Dalam kaitannya sebagai penguasa, kehadirannya preposisi dalam sebuah kalimat ditentunkan pula oleh kategori lain sebagai pembatasnya, dengan kata lain, preposisi disebut sebagai penguasa, sedangkan kategori lain yang konstituen di sebelah kanannya (pendamping kanannya).

\section{Preposisi Gabungan Pole 'dari'}

Preposisi pole 'dari' ini tidak jauh berbeda dengan preposisi elo 'ke' preposisi pole 'dari',verba dinamis yakni lokka 'pergi' lisu 'pulang' sebagai penguasa memicu hadirnya preposisi yang mempunyai ciri dinamis, yakni pole/ datang 'dari'.contoh berikut:

(13) Oto / pole / laleng / pole / saliweng / kota / kurini / maddeppungeng / oto pole / ri / tana / Luwu / tana / menre / Bone, (Daud, 1989: 58).

Mobil / datang / dalam / datang / luar / kota / di sinilah / perkumpulan / mobil / datang - dari / tanah / Luwu / tanah / naik / Bone 'Mobil yang datang dalam dan luar kota, di sinilah tempat perkumpulan mobil yang datang dari daerah Luwu dan menuju daerah Bone'.

(14) Si balireng / ladde / pole / ri / La Sabbarak / na bantumi / matuanna

Woroane / ri / darek e (Fachruddin, 1981: 46).

Berlawanan / sekali / datang dari / La Sabbarak / yang hanya / membantumi / martua / lelakinya / mengerjakan / di / kebun. 'berlawanan sekali datang dari La Sakbara yang hanya membantu mertua lelakinya mengerjakan kebun.

Selanjutnya yang dimaksud penulis preposisi gabungan dalam penelitian ini, utuk lebih rincinya dan kedua preposisi ini wajib saling mendampingi atau bergabung sekalipun tidak harus berdampingan, disebabkan jika salah satu preposisi tidak saling 
mendampingi makan makna dan fungsinya tidak berfungsi 'ke' dan 'dari'. Perhatikan rincian data berikut.

(15) Elo' ka lokka elo + ri kamps'e magguru

'Saya mau kekampus belajar'.

(16) Elo'I La Melleng lokka elo + ri darek na mattaneng relle.

'La Mellong mau ke kebunnya menanam jagung'.

\section{Unsur Linguistik yang Berhubungan dengan Preposisi Bahasa Bugis}

Kehadiran frasa preposisi dalam sebuah kalimat dipicu oleh verba. Dengan kata lain, verba sebagai penguasa memicu hadirnya frasa preposisi sebagai pembatas hubungan, dalam kaitan ini, verba sebagai penguasa menghendaki hadirnya frasa preposisi sebagai pembatas. Verba aktivitas pergi, pulang dan datang sebagai penguasa senantiasa menghendaki hadirnya frasa preposisi ke, dari, sebagai pembatas.kenyataan bahwa verba pergi dan datang dapat diikuti preposisi ke dan dari yang nominanya menyatakan tempat disebabkan oleh kesamaan makna yang ada pada kedua verba itu, yakni keduanya mengandung makna gerak. Dapat dikatakan bahwa kehadiran frasa preposisi dalam sebuah kalimat sangat bergantung pada makna yang terkandung dalam verba predikat kalimat (predikat verbal).

Verba yang dimaksud adalah jenis verba yang berdasarkan ciri seman-tisnya. Berdasarkan maknanya, verba dapat dikelompokkan menjadi dua, yakni verba dinamis dan verba statif, Djajasudarma, 1986, 1991b; Sobarna, 1988, 1995: 31 (dalam Rostina, 1997: 46). Verba dinamis meliputi jenis verba aktivitas, proses, sensasi tubuh, dan peristiwa transisional. Verba statif meliputi jenis verba dengan pengertian persepsi lamban, dan relasional.

\section{Verba}

Bertitik tolak pada pendapat Chafe tersebut, Tampubolon, 1979: 11-30 (dalam Wagiati, 2014: 48) merumuskan bahwa ada tiga tipe utama verba atau kerja dasar, yaitu verba atau kata kerja keadaan, verba atau kata kerja proses, dan verba atau kata kerja aksi. Sogono dan Titik Indiyastini, (1994: 33) menjelaskan bahwa verba yang bermakna keadaan adalah verba yang tidak dapat dipakai untuk menjawab pertanyaan “apa yang dilakukan subjek ataupun apa yang terjadi pada subjek ?". verba ini dapat dipakai untuk menjawab pertanyaan "Bagaimana subjek ?".

Verba keadaan menyatakan bahwa acuan verba berada dalam situasi tertentu. Verba ini tidak dapat dipakai untuk membentuk kalimat perintah. Berdasarkan penjelasan tersebut, verba suka, mati, hilang, takut, berguna, atau terdengar, merupakan contoh verba keadaan. Verba yang bermakna proses dapat dipakai untuk menjawab pertanyaan "apa yang sedang terjadi pada subjek?".

Verba proses juga menyatakan adanya perubahan dari satu keadaan ke keadaan yang lain. Tidak semua verba ini dapat dipakai untuk membentuk kalimat perintah. Berdasarkan penjelasan tersebut, verba jatuh, tumbuh, roboh, mengering, mengecil, menyebar, meluncur, terbakar, atau terdampar merupakan contoh verba proses. Sementara itu, verba yang bermakna perbuatan atau verba aksi adalah verba yang dapat dipakai untuk menjawab pertanyaan "apa yang dilakukan oleh subjek?".

Selain itu, verba perbuatan atau verba aksi dapa dipakai untuk membentuk kalimat perinta. Berdasarkan penjelasan tersebut, verba pergi, lari, mandi, berjalan, bercerita, mendekat, membuka, mengunjungi, atau ditarik merupakan contoh verba perbuatan atau verba aksi Sugono dan Titik Indiyastini, 1994: 32 (dalam Wagiati, 2014:). 
Dalam kalimat, verba sebagai predikat dapat menguasai kemunculan preposisi. Preposisi yang hadir merupakan pembatasnya. Verba yang menguasai preposisi tersebut, berdasarkan bentuknya, berdasarkan maknanya verba dapat dibagi menjadi dua yaitu:

\section{Verba Dinamis}

Verba Dinamis selalu memicu hadirnya preposisi yang mempunyai ciri dinamis. Dinamis ialah verba yang menggambarkan adanya aktivitas atau perbuatan yang dilakukan oleh subjek. Verba dinamis meliputi verba aktivitas, proses tubuh, dan peristiwa transisional. perhatikan contoh berikut:

(17) Elo'/ ka/lokka / ri / dare'e.

Mau / saya / pergi / di / kebun

'Saya mau pergi ke kebun'.

(18) $\mathrm{Ka} /$ elo / lokka / dare'e

Saya / mau / pergi / dare'e

'Saya mau pergi ke kebun'.

\section{Verba Statif}

Verbastatif meliputi jenis verba dengan pengertian persepsi lamban, dan relasional. Verba statif adalah verba yang tidak memerlukan usaha atau tenaga,Verba statif menguasai preposisi elo 'ke', penguasa tersebut ada yang bersifat wajib dan relasional. Perhatikan data berikut pada contoh:

(18) Elo / ka / matinro / ri / kamara'e / ro. mau / saya / tidur / di / kamar / itu 'saya mau tidur di kamar itu'.

(19) Elo / ka / cemme / ri / kollang'e.

mau / saya / mandi / di / kolam / itu

'Saya mau mandi di kolam itu'.

Verba aktifitas pergi, pulang, dan datang sebagai penguasa senantiasa menghendaki hadirnya frasa preposisional elo 'ke', dan pole 'dari' sebagai pembatas.kenyataan bahwa verba pergi dan datang dapat di ikuti preposisi elo 'ke' dan pole 'dari' yang nominanya menyatakan tempat disebabkan oleh kesamaan makna yang ada pada kedua verba itu, yakni keduanya mengandung makna gerak. Dapat dikatakan bahwa kehadiran frasa preposisi dalam sebuah kalimat sangat bergantung pada makna yang terkandung dalam verba predikat kalimat (predikat verbal).

Tajuddin (1993) membagi verba bahasa Indonesia ke dalam empat bagian: verba fungtual, aktivitas, statis, dan verba statif. Perbedaan verba statis dan statif adalah pada ada-tidaknya usaha atau tenaga yang diperlukan dan pada lama waktu yang dibutuhkan. Verba statis adalah jenis verba yang memerlukan tenaga atau usaha dan berlangsung dalam waktu yang terbatas, misalnya: duduk, berdiri, dan tidur, sedangkan verba statif adalah verba yang tidak memerlukan usaha atau tenaga, misalnya: tahu, cinta, dan mendengar dan tidak pula terbatas waktunya.

Verba statis duduk, tidur, dan tinggal menghendaki hadirnya preposisi di yang mengandung ciri statis pula, perhatikan contoh berikut:

(20) duduk di tidur di tinggal di Vprep Vprep $\quad$ Vprep

(21) a. Andi duduk di kursi.

b. Pak Andi tidur di kamar tamu.

c. Andi tinggal di makassar. 
Verba intransitif yang bermakna statis, antara lain, terdapat pada verba $d u d u k$, berdiri, tidur, dan berbaring. Pemakaian verba tersebut di dalam kalimat,pada umumnya menguasai preposisi di, verba statis yang dimaksud di antaranya adalah berkembang, hidup, diam, beristirahat, dan berlinang pada data betikut contoh dalam bahasa Bugis:

Unga / yaro / takbakka'i / ri / compakna / mata / esso

Bunga / itu / berkembang / ri munculnya / mata / hari

'Bunga itu berkembang di pagi hari'.

(23) Atuo-tuongeng'e / ri / lino / masompah / lao / ri / Puang'e

Hidup / di / dunia / menyembah / kepada / Allah

'Hidup di dunia untuk menyembah Allah'.

(24) Andi / makkaca-kaca / mattana/ di / salai / emma' na

Andi / berlinang / matanya / di / tinggal / ibuny

'Andi berlinang air matanya saat di tinggal ibunya'.

Penguasa verba atas preposisi tersebut bersifat tidak wajib. Akan tetapi, sebenarnya lokasi yang menjadi tumpuan peristiwa secara semantis inklusif terkandung di dalam makna verba. Oleh sebab itu, lokasi bersifat lokasi dalam (inner locative).

Pemberlakuan reduplikasi, umpamanya, pada keempat kelas verba itu sebagian besar menghasilkan makna aspektualitas yang berbeda-beda (Tajuddin, 2005: 76).

(a) Reduplikasi pada verba pungtual menghasilkan makna aspektualitas interatif (perulangan), misalnya, pikul-pukul, potong-potong, anggukangguk, datang-datang, dan batuk-batuk.

(b) Reduplikasi pada verba aktivitas menghasilkan makna atenuatif (kealakadaran atau tidak sungguh-sunggu), misalnya, makan-makan, minum-minum, jalan-jalan, lari-lari, nyanyi-nyanyi, dan baca-baca.

(c) Reduplikasi pada verba statis, sama seperti pada verba aktivitas, menghasilkan makna atenuatif, misalnya, duduk-duduk, berdiri-berdiri, dan baring-baring.

(d) Reduplikasi pada verba statif menghasikan dua kemungkinan: (i) tidak gramatikal, misalnya, *cinta-cinta, *percaya-percaya, *yakin-yakin, *mengerti-mengerti. Atau (ii) gramatikal dengan makna aspektualitas diminutif (agak sedikit), misalnya, pening-pening, pegal-pegal, sakit-sakit, dan gatal-gatal.

Verba pungtual adalah yang menguasai kemunculan preposisi dalam penelitian, di antaranya adalah mate 'mati', teppa 'hinggap', lette 'pindah',tama' 'masuk', leppe 'lepas', dan luttu 'terbang'. Namun berbeda dalam bahasa Bugis, dalam bahasa Bugis sesuatu yang agak kecil dalam nomina akan di reduplikasi misalnya, anak bayi (anakanak), burung ( manuk-manuk). Perhatikan contoh data berikut.

(21) Manu-manu / matei / ri / jakbana

Burung / mati / di / sangkar

'Burung itu mati di sangkarnya'.

(22) Pella-pella / yaro / teppai / ri / laleng / pola

Kupu-kupu / itu / himggap / ri / dalam / rumah

'Kupu-kupu itu hinggap di dalam rumah'. 
Verba mate 'mati' dan teppa 'hinggap' masing-masing menguasai $r i$ 'di', verba lette 'pindah' dan tama 'masuk' masing-masing menguasai preposisi elo 'ke' dan verba leppe ' lepas menguasai preposisi pole 'dari'. Penguasaan verba atas preposisi tersebut berkaitan erat dengan proses keberlangsungan peristiwa yang dinyatakan verba.

Hanafie, (1992: 234) menjelaskan subkategori verba dalam bahasa Bugis, ciriciri verba dapat diketahui dengan mengamati (1) bentuk perilaku morfologi, (2) perilaku sintaktik, dan (3) perilaku semantiknya secara menyeluruhdalam kalimat. Namun, secara umum V dapat diidentifikasi dan dibedakan dari kelas kata lain terutama A karena ciri berikut: (a) V berfungsi utama sebagai predikat atau sebagai inti predikat dalam kalimat, walaupun dapat juga mempunyai fungsi lain; (b) V mengandung makna dasar perbuatan (aksi), proses, atau keadaan yang bukan sifat atau kualitas; (c) V khususnya yang bermakna keadaan tidak dapat diberi prefiks maq-, misalnya *mattuwo dari tuwo 'hidup', *maengka dari engka ' ada'. A reduplikasi + frasa

Komponen pertama berupa A reduplikasi diikuti oleh frasa $\mathrm{N}$ dan me-nyatakan $\underline{b}$ keadaan $\underline{a}$ atau ahasil $\underline{b}$, misalnya: atuo-tuong ri lino 'kehidupan di dunia' (mata pencaharian).

Jenis kategori penguasa-pembatas preposisi dalam bahasa Bugis. Kategori yang menjadipenguasa hadirnya sebuah preposisi dalam kalimat adalah jenis kategori verba. Dengan kata lain, frasa preposisi sebagai pembatas hubungan ditentukan oleh kategori verba yang menjadi penguasanya.

Dalam hal ini, preposisi dalam sebuah kalimat berlaku sebagai pembatas. Di pihak lain (frasa preposisi), preposisi berlaku sebagai penguasa. Dalam kaitannya sebagai penguasa, kehadiran preposisi dalam sebuah kalimat ditentukan pula oleh kategori lain sebagai pembatasnya.

\section{Adverbia / Modalitas}

Kridalaksana, (2008: 81) menjelaskan adverbia adalah kategori yang dapat mendampingi ajektiva, numeralia, atau proposisi dalam konstruksi sintaksis. Dalam kalimat ia sudah pergi, kata sudah adalah advervia, bukan karena mendampingi verba pergi, tetapi karena mempunyai potensi untuk mendampingi adjektiva, misalnya dalam saatnya sudah dekat. Jadi, sekalipun banyak adverbia dapat mendampingi verba dalam konstruksi sintaksis, namun adanya verba itu bukan menjadi ciri adverbia. Adverbia tidak boleh dikacaukan dengan keterangan, kareana adverbia merupakan konsep kategori, karena adverbia merupakan konsep kategori; sedangkan keterangan merupakan konsep fungsi.

Adverbia dapat ditemui dalam bentuk dasar dan bentuk turunan. Bentuk turunan itu terwujud melalui afiksasi, reduplikasi, gabungan proses, gabungan morfem.Jika dilihat dari batasan dan ciri adverbia, adverbiah adalah kata yang menjelaskan verba, adjektiva, atau adverbia lain.

(1) Adverbia dasar bebas

(2) Adverbia turunan terbagi atas:

(a) Adverbia turunan yang tidak berpindah kelas terdiri dari:

i. Adverbiah berreduplikasi contoh:

(27) Manu-manu'/ mattarata'i / ri / yase'na / pong'e

Burung / bertengger / di / atas / pohon

'Burung itu bertengger di atas pohon'.

Bola-bola / yaro / engka / ri / galung'e 
Rumah / itu / ada di / sawah

'Rumah kecil itu / pondok ada di sawah'.

(29) Ana-ana' / yaro / matinro / ri / perek / na

Anak / itu / tidur / di / ayun / nya

'Anak kecil itu sedang tidur di ayunnya'.

Pada contoh data (27)-(29) adverbia manu-manu 'ayam', bola-bola 'rumah', dan ana-ana 'anak' merupakan reduplikasi di dalam bahasa Bugis, di dalam bahasa Bugis nomina dan kata benda yang kecil selalu di reduplikasi, adverbia yang di ikuti preposisi ri 'di' menerangkan adverbiareduplikasi turunan.

Selanjutnya salah satu alat uji bahwa sebuah frasa preposisi yang menduduki keterangan pada adverbia yang mengikuti frasa preposisi, dapat diuji dengan teknis permutasi seperti pada data berikut contoh.

(30) Ri / yase'na / pong'e / mattarata'i / manu-manu

$\mathrm{Di} /$ atas / pohong / bertengger / burung

'Di atas pohon itu bertengger burung'.

(31) Ri / galung'e / ro / engka / bola-bola

Di / sawah / itu / ada / rumah kecil

'Di sawah itu ada pondok-pondok'.

(32) Ri / perek'na / yaro / ana-ana / matinroi

Di / ayunan / itu / anak kecil / tidur

'Di ayunan iu anak anak kecil tidur'.

\section{Ingin}

Pada umumnya para pakar bahasa menjelaskan kata yang menjelaskan verba, adjektiva, atau adverbia lain. Namun tidah jauh berbedah dalam bahasa Bugis perhatikan contoh berikut:

(33) Elo / ladde / ka /lokka / ri / kampus'e

Mau / sekali / saya / di / kampus

'Saya ingin sekali pergi ke kampus'.

(34) Elo / ladde / ka / lokka / ri / galung'e / mattaneng / ase

Mau / sekali / saya / pergi / di / sawah / menanam / padi

'saya ingin sekali pergi ke sawa menam padi'

Pada data (33)-(34) menjelaskan preposisi ri kampus'e 'di kampus', ri galung'e 'di sawah', dan ri makssar ' di makassar' mengalami perubahan makn ketika didahului oleh modalitas 'elo' yang bermakna 'ingin'. Dengan demikian, modalitas elo 'ingin' yang berkorelasi denga frasa preposisi $r i$ 'di' mengubah makna $r i$ 'di' menjadi ke 'ingin',yang menjelaskan frasa preposisional bermakna keterangan tempat yang dapat dijadikan patokan sebagai ciri adverbia tidak hanya berfungsi kata atau bagian kalimat yang diterangkan teapi juga kategorinya.

\section{Mau}

(35) Elo / ka / makkuliah / ri / jepang

Mau / saya / kuliah / di / bandung

'Saya mau kuliah di jepang'

(36) Elo / ka / mitai / pertandingan / sepak / bola / ri / lapangang'e

Mau / saya / lihat / pelombaan / sepak / bola / di / lapangan /

'Saya mau menonton perlombaan sepak bola di lapangan'.

Contoh pada data (35)-(36) menjelaskan modalitas yang menandai peristiwa yang belum terjadi 'elo' yang bermakna 'ingin', ri jepang 'di jepang', ri lapangang'e 
'dilapangan', dan ri kollang'e 'di kolam', 'elo' yang bemakna 'ingin' diikiuti oleh preposisi ri 'di'.

\section{Fungsi Preposisi dalam Bahasa Bugis}

Dalam kalimat frasa preposisional dapat menduduki fungsi predikat dan keterangan. Fungsi keterangan merupakan fungsi yang umum diduduki oleh frasa preposisional.

\section{Predikat}

Predikat merupakan konstituen pokok yang disertai konstituen subjek di sebelah kiri dan, jika ada, konstituen objek pelengkap, atau keterangan wajib di sebelah kanannya, predikat kalimat biasanya berupa frasa verbal atau frasa adjek-tival. Pada kalimat yang berpola SP, predikat dapat pula berupa frasa nominal, frasa numeral, atau frasa preposisional, di samping frasa verbal dan frasa adjek-tival (Alwi, 2003: 326).

Sugono, 1997: 48-54 (dalam Wagiati, 2014:77) memberikan ciri-ciri predikat dalam bahasa Indonesia di antaranya adalah (i) jawaban atas pertanyaan mengapa atau bagaimana, (ii) berupa kata adalah atau ialah, (iii) dapat diingkar-kan, serta (iv) dapat disertai kata-kata aspek dan modalitas. Selanjutnya, dikemukakannya pula bahwa berdasarkan konstruksinya, predikat dapat berupa (1) kata dan (2) frasa. Adapun berdasarkan kategori kata yang mengisi, predikat dapat diisi oleh verba atau frasa verbal, nomina atau frasa nominal, adjektiva atau frasa adjektival, numeralia atau frasa numeralia, serta frasa berpreposisi (Sugono, 1987 : 55-56).

Namun berbeda dalam bahasa Bugis urutan dalam kalimat bahasa Bugis terdiri dari; P, S + Ket, dan Ket + P, S. Preposisi ri 'di', elo/ mau 'ke', dan pole/datang 'dari', mempunyai makna dan fungsi berbeda-beda dalam bahasa Bugis. Perhatiakn contoh dalam bahasa Bugis ialah;

(37)

$$
\begin{aligned}
& \text { Makkuliah / ka / ri / Jepang } \\
& \text { P K P Pre Ket } \\
& \text { Kuliah / saya / di /Jepang } \\
& \text { 'Saya kuliah di Jepang' }
\end{aligned}
$$

Pada data (37) Frasa preposisi dapat menduduki fungsi sebagai keterangan makkuliah $k a$ 'kuliah', merupakan predikat dari dari tiap-tiap subjek $k a$ 'saya'.

Salah satu alat uji bahwa sebuah frasa preposisi tersebut menduduki fungsi keterangan dapat di uji teknik permutasi seperti data berikut ini.

\section{Ri / Jepang / makkuliah / ka}

Di / Jepang / kuliah / saya

'DiJepang saya kuliah'.

\section{Pelengkap}

Sogono, 1997: 69 (dalam Wagiati, 2014: 80) menjelaskan bahwa peleng-kap dan objek memiliki kesamaan. Kesamaan itu ialah kedua unsur kalimat ini (1) bersifat wajib (harus ada karena melengkapi makna verba predikat kalimat), (2) menempati posisi belakang predikat, dan (3) tidak didahului preposisi. Perbedaan-nya terletak pada oposisi kalimat pasif. pelengkap tidak menjadi subjek dalam kalimatpasif. Jika terdapat objek dan kalimat di belakang predikat kalimat aktif, objeklah yang menjadi subjek kalimat pasif, bukan pelengkap.

Berdasarkan hal-hal yang dikemukakannya itu, Sugono memberikan ciri-ciri tentang pelengkap antara lain (i) di belakang predikat secara langsung; kecuali dalam kalimat dwitransitif, pelengkap berada di belakang objek, (ii) tidak di-dahului preposisi, dan (iii) tidak dapat menjadi subjek dalam kalimat pasif Sugono, 1997: 69- 
-72 (dalam Wagiati, 2014: 80). Berdasarkan ciri-ciri tersebut, konstituen yang dicetak miring pada contoh berikut adalah pelengkap.

(38) a. Tindakan ini / berdasarkan / hukum.

b. Desa kami / kedatangan / tamu penting.

c. Dia / membuatkan / saya / kopi susu.

Paddairiolo 'preposisi' dalam bahasa Bugis yang didampingi oleh pe-lengkap. Perhatikan contoh berikut:

(39) Ambo / ku / nappai / lisu / pole / ri / galung' / e

Bapak / saya / baru / pulang / datang / dari / sawah / itu

'Bapak saya baru pulang dari sawah itu'.

(40) Emma / ku / mannasu / nanre / ri / daputeng'e

Ibu / saya / memasak / nasi / di / dapur

'Ibu saya sedang memasak nasi di dapur'.

(41) Andi / ma'dangkang / barang-barang / bekas / ri / pasa'e

Andi / menjual / barang-barang / bekas / di / pasar

'Andi menjual barang-barang bekas di pasar itu'.

Selanjutnya salah satu alat uji bahwa sebuah frasa preposisi tersebut menduduki frasa fungsi pelengkap, dapat diujin dengan teknis permutasi seperti pada contoh data berikut.

(42) Ri / galung'e / nappai / lisu / Ambo' / ku.

Di / sawah / baru / pulang / Bapak / saya

Dari sawah Bapak saya baru pulang'.

(43) Ri / daoureng'e / emma / ku / mannasu / nanre.

$\mathrm{Di} /$ dapur / ibu / saya / memasak / nasi

'Di dapur ibu sasya memasak nasi'.

(44) Ri / pasa'e / Andi / ma'dangkang / barang-barang / bekas.

Di / pasar / Andi / menjual / barang-barang / beksa

'Di pasar Andi menjual barang-barang bekas'.

\section{Keterangan}

Keterangan merupakan fungsi sintaksis yang paling beragam dan paling mudah berpindah letaknya. Keterangan dapat berada di akhir, di awal, dan bahkan di tengah kalimat. Pada umumnya, kehadiran keterangan dalam kalimat bersifat manasuka. Konstituen keterangan biasanya berupa frasa nominal, frasa pre-posisional, atau frasa adverbia. Perhatikan contoh berikut.

(45) a. Andi mencuci bajunya hari ini

b. Andi mencuci bajunya di sungai

c. Andi mencuci bajunya dengan rinso

d. Andi mencuci bajunya kemarin

Selain oleh satuan yang berupa kata atau frasa, fungsi keterangan dapat pula diisi oleh klausa seperti pada contoh berikut:

(46) a. Dia memotong rambutnya sebelum dia mendapat peringatan dari sekolah

b. Dia memotong rambutnya segera setelah dia diterima bekerja di bank.

Makna keterangan ditentukan oleh perpaduan makna unsur-unsurnya. Dengan demikian, keterangan di sungai pada contoh (45b) mengandung makna tempat, dengan rinso (45 c) mengandung makna alat, kemarin (45d) menyatakan makna waktu, dan sebelum dia mendapatkan peringatan dari sekolah (46 a) serta segera setelah dia 
diterima bekerja di bank (46 b) juga mengandung makna waktu (Alwi, dkk., 2003: 331).

Unsur di kamar di sungai, dengan rinso dan kemari pada contoh di atas merupakan keterangan yang sifatnya manasuka.

Begitupula Paddairiolo 'preposisi' dalam bahasa Bugis yang didampingi oleh keterangan. Fungsi yang umum diduduki oleh frasa preposisi adalah keterangan. Posisi keterangan dalam kalimat dapat bermacam-macam, yaitu di belakang, di tengah, dan di depan. Perhatikan contoh berikut:

(47) Ri / dapureng'e / ro / emma / ku / mannasu / nanre di / dapur / itu / ibu / saya / memasak / nasi

'Di dapur itu ibu saya sedang memasak nasi'.

(48) Nasaba / maccai / anak-anak / yaro / runtu'i / beasiswa Disebabkan / pintar / anak / itu / mendapat / beasiswa 'Karena pandai anak itu mendapat beasiswa'.

(49) Makkokoe / tauwe / maccani / maebbu / teknologi / magello Sekarang / manusia / pintar / membuat / teknologi / bagus

'Sekarang manusia telah dapat menciptakan teknologi canggi'.

Pada umumnya fungsi keterangan diletakkan di akhir kalimat. Sebenarnya, posisi tersebut secara pragmatik bergantung pada tujuan penutur dalam hal mementingkan unsur kalimat. Apabali yang dipentingkan adalah fungsi keterangan, frasa preposisi diletakkan di awal kalimat, atau di tengah kalimat setelah fungsi subjek. Akan tetapi, tidak semua frasa preposisi memiliki kebebasan seperti itu.

\section{Makna Preposisi Tempat dalam Bahasa Bugis}

Preposisi pada dasarnya menandai pertalian antara kata atau frasa yang mengikutinya atau yang disebut aksis, dengan kata/frasa lain dalam kalimat/frasa yang lebih besar. Preposisi hanya mempunyai makna jika terdapat dalam kalimat, preposisi yang menyatakan tempat dapat dibagi menjadi tiga yakni; (1) yang menyatakan tempat berada 'lokasi', (2) yang menyatakan tempat asal, dan (3) yang menyataka tempat tujuan 'arah'.

\section{Lokasi}

Preposisi $r i$ 'di' digunakan di depan kata benda yang menyatakan nama tempat baik nama kota, desa, maupun nama ruang / tempat lainnya. Paddairiolo 'Preposisi' yang bervariasi lokasi dalam bahasa Bugis, perhatikan contoh berikut pada data:

Ri / kampong- kampong / maega / ana-ana / dena / lanjuk / massikolah

Di / kampung-kampung / banyak / anak-anak / tidak / lanjut / sekolah

' $D i$ kampung-kampung banyak anak-anak tidak lanjut sekolah'.

(51) Pole / ka / cemme / ri / kollang'e.

Datang / saya / mandi /di / kolam itu

'Saya datang mandi di kolam itu'.

Pada data (50)-(51) menandai penggunaan preposisi $r i$ 'di' yang memiliki makna lokasi berupa nama tempat, kota, dan desa. Pemakaian paddairiolo 'preposisi' ri 'di' pada pada contoh-contoh data diatas tidak dapat disubsitusi dengan preposisi yang lain, sedangkan penempatannya dapat saja dipermutasikan. Namun keberadaannya dalam kalimat tetap menduduki fungsi keterangan. 
Untuk menyatakan tempat berada yang lebih tepat dan lebih khusus, preposisi $r i$ 'di' dapat diikuti kata yang menjadi bagian dari tempat dimaksud, baik kata yase 'atas', yawa 'bawah', laleng 'dalam',sedde 'samping', munri 'belakang', maupun yolo 'depan'.

Salah satu alat uji bahwa sebuah frasa preposisi tersebut menduduki fungsi keterangan dapat diuji dengan teknis permutasi seperti contoh berikut:

(52) Maega / ana-ana / dena / lanju / messikolah / ri / kampongkampong'e

Banyak / anak-anak / tidak / lanjut / sekolah / di / kampungkampung

'Banyak anak-anak tidak lanjut sekolah di kampung-kampung'.

(53) $\mathrm{Ri} /$ kollang'e / ro / pole / ka / cemme

Di / kolam / itu / datang / saya / mandi

'Di kolam itu saya datang mandi'.

(54) Ri / Jepang / monro'i / Ambo / ku

Di / Jepang / tinggal / bapak / saya

'Di Jepang bapak saya tinggal'.

(55) Ri / Amerika / Andi /lanju'i / makkuliah

Di / Amerika / Andi / lanjut / kuliah

'Di Amerika Andi lanjut kuliah'.

(56) $\mathrm{Ri}$ / pong'e / yaro / mattrata'i / manu-manu

Di / pohon / itu / brtengger / burung

'Di pohon itu bertengger burung

Asal

Paddairiolo 'Preposisi'yang bervariasi asal dalam bahasa Bugis yang menyatakan tempat yaitu pole 'dari'. Preposisi pole 'dari'digunakan di depan kata benda yang berupa nama tempat, dan dapat digunakan di depan kata benda yang berupa orang (bernyawa). Di bawah ini adalah contoh penggunaan preposisi pole 'dari' yang bermakna asal yang digunakan di depan kata bendatidak bernyawa

(57) Pole / ka / ri / dare'e / mattaneng / ase datang / saya / di/ kebun / menanam / padi 'Saya datang dari kebun menanam padi'.

(58) Makkoniro / La Mani / tungke-tungke / engkai / wurane na / pole / ri / darek'e (fachruddin, 1981: 47).

Begitu lah / La Mani / selalu sendiri / ada dia / suaminya/ datang di / kebunya

'Begitulah La Mani selalu sendiri suaminya darang dari kebunya'.

(59) Pole / ka/ri/makassar.

Datang / saya / di / makassar

'Saya datang dari makassar'

(60) Sibawa / ku/pole / ri / kampus'e

Teman / saya / datang / di / kampus

'Teman saya datang dari kampus'

Kemudian preposisi pole 'dari' yang juga menyatakan 'asal' dapat digunakan di depan kata benda yang berupa orang (bernyawa), seperti pada data berikut dalam contoh: 
(61) Mattarima / ka / hadiah / pole / ambo'/ ku

Menerimah / saya / hadiah / datang dari / bapak / saya

'Saya menerimah hadiah dari bapak saya'.

(62) Book/yae / wutarimah / pole / ri / guruk / ku

Buku / ini / saya terimah / datang dari / di / guru / saya

'Buku ini saya terimah dari guru saya'.

(63) Waju / yae / abbereang / pole / ri / emma / ku

Baju / ini / pemberian / datang dari / di / ibu / saya

'Baju ini pemberian dari ibu saya'

Arah

Paddairiolo 'Preposisi' yang bervariasi arah atau menyatakan tujuan dalam preposisi bahasa Bugis digunakan preposisi elo 'ke', preposisi elo 'ke' berada di depan nama tempat tertentu, seperti kampus, pasar, dan masjid. Perhati-kan pada contoh data berikut:

Elo / ka / lokka / ri / kampus' / e / magguru

Mau / saya / pergi / di / kampus / itu / belajar

'Saya mau pergi ke kampus untuk belajar.

(65) Elo / ka / lokka / ri / pasa'e / mangelli / waju.

mau / saya / pergi / di / pasar itu / membeli / baju

'Saya mau ke pasar membeli baju'.

(66) Elo’i /lokka / ambo / ku / ri / masiji'e / massumpajang /

juma'

Mau / pergi / bapak / saya / di / masjid / salat / jum'at

'Bapak saya mau ke masjid salat jum'at'

Preposisi elo 'ke' digunakan di depan kata benda yang bukan orang, baik kata benda yang menyatakan nama tempat, nama kota, maupun negara.contoh data berikut:

(67) Elo / ka / lokka / makkuliah / ri / Jepang / sibawa / Andi

Mau / saya / pergi / kuliah / di / Jepang / sama /Andi

'Saya mau pergi kuliah ke Jepang bersama Andi'.

(68) Elo / ka / lisu / ri / makassar / mattaung / paru

Mau / saya / pulang / di / makassar / tahun / baru

'Saya mau pulang ke makssar tahun baru'.

Elo / ka / lokka / cemme / ri / kollang'e / ro

Mau / saya / pergi / mandi / di / kolam / itu

'Saya mau pergi mandi ke kolam itu'.

Begitu pula dengan preposisi elo 'ke' dalam bahasa bugis yang menyatakan tempat tujuan digunakan di depan kata yang menyatakan nama orang dan nama tempat tertentu yang bukan merupakan nama wilayah atau nama kota, perhatikan contoh data berikut:

(70) La Andi / lokka/ ni / akko / daeng / na

Si Andi / pergi / dia / ke / kaka / nya

'Si Andi sudah pergi ke kakanya'.

(71) Paletturenngi / addatungeng / yae / akko / emma / na

Sampaikan / kiriman / ini / ke / ibu / nya

'Sampaikan kiriman ini ke ibunya'.

Salah satu alat uji bahwa sebuah frasa preposisi tersebut menduduki fungsi keterangan dapat diuji dengan teknis permutasi seperti contoh berikut:

(72) Taon / baru / elo / ka / lisu / ri / makassar

Tahun / baru / mau / saya / pulang / di / makssar 
'Tahun baru saya mau pulang ke makssar'.

(73) Sibawa / ka / Andi / elo / lokka / makkuliah / ri / Jepang

Sama / saya / Andi / mau / pergi / kuliah / di / Jepang

'Saya bersama Andi mau pergi kuliah ke Jepang'.

(74) Ri / kollang'e / ro / elo / ka / lokka / cemme

Di / kolam / itu / mau / saya / pergi / mandi

'saya mau pergi ke kolam itu mandi'.

\section{SIMPULAN}

Berdasarkan hasil deskripsi dan analisis yang telah dilakukan dalam penelitian preposisi dalam bahasa Bugis ini didaftar sebanyak tiga buah preposisi dalam bahasa Bugis. Dari segi bentuk preposisi dalam bahasa Bugis digolongkan menjadi dua kelompok, yakni (1) preposisi tunggal, dan (2) preposisi gabungan.

Preposisi dikenal dalam bahasa Bugis dengan sebutan paddairiolo atau kata depan. Preposisi yang bermakna tempat dalam bahasa Bugis yaitu (1) Ri 'di', (2) Elo 'ke', dan (3) Pole 'dari'. Unsur linguistik yang berhubungan dengan preposisi dalam bahasa Bugis (1) Verba dinamis dan (2) Verba statif.meliputijenis verba aktifitas, proses, dan sensasi tubuh yakni keduanya mengandung makna gerak. Dapat dikatakan bahwa kehadiran frasa preposisi dalam sebuah kalimat sangat bergantung pada makna yang terkandung dalam verba predikat kalimat (predikat verbal).

Berdasarkan kategori penguasa-penguasa preposisi, preposisi dalam bahasa Bugis dapat menjadi penguasa dan dapat pula berlaku pembatas hubungan. sebagai penguasa, preposisi dalam bahasa Bugis, verba dinamis yakni lokka 'pergi' lisu 'pulang' sebagai penguasa memicu hadirnya preposisi yang mempunyai ciri dinamis, yakni elo/ mau 'ke', pole/ datang 'dari'.

Konstruksi urutan fungsi sintaksis dalam kalimat bahasa Bugis terdiri dari; (1) Predikat, (2) Subjkek, dan (3) Keterangan, preposisi ri 'di'. elo 'ke', dan pole 'dari' mempunyai makna dan fungsi yang berbeda-beda dalam bahasa Bugis. Makna tempat yeng terkandung dalam bahasa Bugis yaitu, (1) Lokasi, (2) Asal, dan (3) Arah.

\section{DAFTAR PUSTAKA}

Alwi, Hasan. 2003. Tata Bahasa Baku. Jakarta: Balai Pustaka.

Alisjahbana, S. Takdir. 1986. Tata Bahasa Baru Bahasa Indonesia. Jilid 2.Jakarta: Dian Rakyat. Bandung: Angkasa.

Djajasudarman, T. Fatimah. 2013. Semantik 2 Relasi Makna Paradigmatik, Sintagmatik, dan Derivasional. Bandung: PT. Refika Aditama.

Daud, Drs. M. dkk. 1998. Muatan Lokal Untuk SLTP Sulawesi Selatan. Ujung Pandang.

Fachuddin, A.E., dkk. 1989. Sastra Lisan Bugis. Jakarta: Pusat Pembinaan dan Pengembangan Bahasa Departemen Pendidikan dan Kebudayaan.

Hanafie, Sitti Hawang. 1992. "Kelas Kata dalam Bahasa Bugis: Kajian Morfologi Lingkup Kelas Verba, Adjektiva, dan Nomina" Tesis. Universitas Hsanuddin Ujung Pandang.

Kridalaksana, Harimurti. 1985. Kelas Kata Bahasa Indonesia. Jakarta: Gramedia. 
Mattulada, H.A.1995. Latoa, Satu Lukisan Aanalisis terhadap Antorpologi Politik Orang Bugis, Ujungpandang; Hasanuddin University Press.

Padindang, H. Ajiep. 2007, Tradisi Masyarakat Islam di Sulawesi Selatan, Makassar; Lamacca Press.

Rafiuddin. 1980. Aku Bangga Berbahasa Bugis, Bahasa Bugis dari ka sampai ha.Makassar: de la macca.

Ramlan, M. 1980. Kata Depan atau Preposisi dalam Bahasa Indonesia. Yogyakarta: UP Karyono.

Riady, Asmat lemellong. 2011. Kamus Lengkap Bahasa Bugis. Makassar: de la macca.

Rostina. 1997. "Preposisi dalam Bahasa Aceh". Bandung: Tesis.Gramedia Pustaka Utama.

Sobarna, Cece. 2012. Preposisi Bahasa Sunda. Bandung: SYABAS BOOKS

Sudaryanto, 2015. Metode dan Aneka Teknik Anlisis Bahasa. Yogyakarta: Universitas Sanata Dharma Anggota APPTI.

Samsuri. 1981. Analisis Bahasa . Jakarta: Erlangga.

Tadjuddin, Moh. 2005. Makna Aspektualitas Dalam Kajian Linguistik. Bandung: P.T. Alumni.

Wedhawati, dll. 1990. Preposisi Dalam Bahasa Jawa. Jakarta: Agung tamtama.

Wagiati. 2014. "Konstruksi Berstruktur Predikat-Subjek dalam Bahasa Indinesia" Disertasi. Fakultas Ilmu Budaya Universitas Padjadjaran Bandung.y Paulsen Books. 